\title{
THE IMPLEMENTATION OF TALKING STICK TO IMPROVE STUDENTS' VOCABULARY MASTERY AT THE TENTH GRADE OF SMA NEGERI 2 KABUPATEN SORONG
}

\author{
Ari Wibowo \\ ariwibowo@unimudasorong.ac.id \\ Nursalim \\ nursalim@unimudasorong.ac.id \\ Fransiska Pindan Sao \\ chikasao@gmail.com
}

\author{
Education University of Muhammadiyah Sorong, Indonesia
}

\begin{abstract}
The students at Senior High School are teenagers. They were easy to feel bored if teacher taught them by a conventional method. They love to learn everything by a fun way. In this case, the writer tries to improve their ability in mastery English vocabulary, which vocabulary is something important to be learnt. It is one element to sharp the four skills of speaking, listening, reading and writing all together. The writer takes a research about this case. This study is mainly aimed to identify the improvement of student's vocabulary mastery through Talking Stick for the tenth grade students of SMA NEGERI 2 KABUPATEN SORONG in the academic year of 2016/2017. This research is a classroom action research. The methods of collecting data are observation, interview, test instrument and field notes. Then, the writer analyzes them in descriptive and statistical technique. This study takes two cycles. After did two cycles, the writer get a result. Both in the cycle I and cycle II, score of post-test are higher than pre-test. Then, the percentage of students' mastery also improve, while in the first cycle there were only $41 \%$ students who could pass the target score of the Minimal Mastery Level Criterion (KKM). In the second cycle, there were $72 \%$ students who could pass the target score. Then from the questioner respond, it seems that students interested in learning vocabulary through Talking Stick. These all results indicate that there was significant improvement of students' vocabulary mastery through Talking Stick for the tenth grade students of SMA NEGERI 2 Kabupaten Sorong in the academic year of $2016 / 2017$.
\end{abstract}

Key Words: Talking Stick, Vocabulary

\section{INTRODUCTION}

English is an international language. It is the absolute truth. No matter with people willingness, whether they agree or not. The fact is English language has been claimed as the International language and still be the international language till now. Being the international language, it means that English is used to do the communication between many countries, also English being the only one language which is unite the differences between countries. Almost every country in the world, use English as the second language after their first language(mother language). By this fact, automatically this language influences all part of life, such 
as music, sport, fashion, entertainment, business, education, etc. This condition demand people to have ability in mastering English language. Looking for this condition, many countries made the English as an obligation lesson, including Indonesia. English lesson being taught for the students in Elementary School, Junior High School, Senior High School and university.

But in fact the students' vocabulary is very low. There are a lot of vocabularies that they have knowing yet. During the writer teaching English at class, there were four skills that is being the assessment of students. There are speaking, listening, reading and writing. Unfortunately, almost of students were got the bad marking. They did not know what English' word they have to write, what was the meaning of word that they listen, what words they have to say when they want to speak and what was the meaning of the word that they read. All words they did not know are vocabularies. The reason why their vocabulary was very low is because they did not improve their vocabulary. The writer have ever asked them why they did not improve their vocabularies, they answered that they don't know how to improve the vocabulary well. They only tried to memorizing a new vocabulary that they just got, but the way of memorizing was a bored way. So they were not care with vocabulary whereas vocabulary is important to be improving. According to Kridalaksana (2008) "vocabulary is a component of language that maintains all information about meaning and using word in a language". It means that vocabulary is the important part of language, without vocabulary the language cannot be used to maintain all information in language and vocabulary will be the key to students understanding everything in doing the communication.

Surely there are a lot of methods and techniques of language teaching that can be selected but not all of the methods may be effective to solve the problem. In this paper, the writer is offering Talking Stick as the way to help students improve their vocabulary. This method is expected to bring the fun atmosphere in the classroom. In this case, it is important to do an implementation to prove whether the method can improve student's ability in improving vocabulary or not. Talking Stick is a method that was developed by Kagan(1992:1). It is a group of study where the students learnt independently from one another: each students has the same chance to express their ideas and concern with equal participant of students. It is one kinds of Cooperative Learning technique. Talking Stick makes students more active and directly join in learning English process, give the big chance between the teacher and students to interaction, the students being self-supporting, and also make the learning activity more fun. Usually, the fun learning activity will make the students feel happy, if they feel happy, of course their enthusiasm to learn is more increase, the material will be received well and they may be able to improve their vocabulary. 


\section{LITERATURE REVIEW}

\section{Previous Related Study}

The first previous study was done by Neaty Muttahidah (2011) entitled Improving Students' Vocabulary through Vocabulary Card (A Classroom Action Research in the First Year of MTs NurulFalah, Ciputat). In her research, she also tries to improve students' vocabulary, which is same with the writer research. The different is she uses the vocabulary card as the way to improve students' vocabulary, meanwhile the author use Talking Stick Method to improve students' vocabulary. The result of this study showed that there was a significant change on students' vocabulary mastery. It can be seen from the mean score of pre-test were 49.6, the mean score of post-test in cycle 1 was 58.0 and the mean score of posttest cycle 2 was 66.3 . In addition, there were 5 students $(16,6 \%)$ who passed Minimum Mastery Criterion-Kriteria Kelulusan Minimal (KKM) in the pre-test. Meanwhile in the cycle 1, there were 18 students (60\%) who passed Minimum Mastery Criterion (KKM) and it gained which was in the post test cycle 2, there were 26 students $(86,6 \%)$ who passed Minimum Mastery Criterion. Then from the questionnaire, it show that there was improvement of positive responses in the teaching-learning process of vocabulary through vocabulary card. So, the criteria success was achieved.

The second previous study was done by Dita Indra Febriyanti(2015) The Use of Talking Stick to Improve Students' Speaking Skill(A Classroom Action Research on X MIA-2 Students of SMA Negeri 1 Kesambean). Dita and the writer are using the same method, which the method is Talking Stick, the difference is she tries to improve students' speaking skill, meanwhile the writer tries improve students' vocabulary mastery. The result of her research showed that there is a significant improvement of students' speaking skill after the implementation of talking stick. The improvement can be seen from the achievement of the two criteria of success. The first criterion is if the students' mean score of post-test gain more than 5 points from the students mean score of pre-test. It is established that the first criterion was accomplished since the students mean score of post-test was 9,43 points higher than the mean score of students' pre-test, from 66,86 on pre-test become 74,19 on the post-test. The second criterion of success is when there were more than $60 \%$ students could passed minimum standard score of English that is 75. This is achieved since the students that could pass minimal standart score of English was $64,86 \%$.

The third previous study was done by Heny Payuyu (2013)with the tile Increasing Students' English Vocabulary Mastery (NUMBER) Through Talking Stick Method in the First Grade of SDN 11 Limboto Barat. This research is an Action Clasroom Research, where this research takes two cycles. On student's ability observation is $21 \%$ or 6 students, in cycle 1 is $58 \%$ or 16 students, and cycle 2 is $98 \%$ or 27 students from 28 students. This study can be concluded that the mastery of students' English Vocabulary (number) through Talking Stick in the 
first grade of SDN 11 Limboto Barat was increased. The similarity of this research is the researcher same in discuses about the using of Talking Stick Method, but the difference is she tries to improve students' mastery of vocabulary in Elementary School grade meanwhile the researcher tries to improve students' vocabulary in Junior High School Grade . The purpose of this study is mainly aimed to identify the improvement of student's vocabulary mastery through talking stick method for the first grade students of SDN 11 Limboto Barat in the academic year of 2012 12013.

\section{Some Pertinent Ideas}

\section{Teaching Vocabulary}

Teaching vocabulary is not easy to do. Some people think that vocabulary teaching only wastes the time because vocabulary number is unlimited. The English teachers had better teach English vocabulary first than other aspect of this language, such as grammar, speaking, reading and writing. If students know more vocabulary, it will be easy for them to learn another aspect of English language.

Vocabulary is a central of English language, acquisition, as according to Celce and Murcia (2001: 285) vocabulary learning is a central to language acquisition whether the language is first, second, or foreign. According to Hornby (1995. p: 125), "teaching" is defined as giving instruction to somebody' knowledge, skill, etc. From that explanation, teaching vocabulary is an activity where the teacher gives the students' knowledge about vocabulary and how to use it in daily life. Harmer (2001: 155) gives the wide explanation about some technique for teaching vocabulary that is summarized as follows:

\section{1) Demonstration}

The teacher demonstrates the he language where he/she wants the students to study by offering them there in action.

2) Explanation

The teacher explains the construction of language in diagram, using textbook, using board or OHP.

3) Discovery

The students can be encouraged to understand new language form by discovering them in a test or by looking at grammatical evidence in order to work out a grammar rule.

\section{4) Check Question}

The teacher can check question to see if students have understood the meaning and use in the text or paragraph.

\section{5) Presentation}

The teacher shows the things and does not present words to students, for example, pictures, video and also use the mime, action and gesture to present the words. 


\section{Teaching English Vocabulary in Senior High School}

The students at Senior High School are teenagers. Teaching English to teenagers is different from teaching English to adult learners. The teenagers have special characteristics (Brown: 2001). First, the operational thought of the teenagers is increasing. They can solve the problems with logical thinking. Second, attention spans of the teenagers are lengthening. This is as a result of intellectual maturation of the teenagers. Third, the teenagers still need varieties of sensory input. Other characteristics of the teenagers are they have a very high ego and self-image and are very sensitive. The last characteristics of the teenagers are they are more and more becoming adult like, so the teachers have to be careful in teaching them.

Teenagers are easy to get bored with the lesson compared with adult learners. They need colorful pictures and information that are relevant with their world. Teaching English vocabulary to teenagers needs an extra work and appropriate teaching method which is adjusted to the studentse need. Therefore, the teachers should be creative in finding interesting ways to teach vocabulary.

\section{METHOD}

\section{Design and Samples}

The method that used in this research is Classroom Action Research (CAR). According to Michael J.Wallace(2006) in his book Action Research for Language Teacher, Classroom Action Research is a type of classroom research carried out by the teacher in order to solve problem or to find answers toward context-specific issues. It means that before do the implementations of Classroom Action Research, the writer, the researcher or the teacher have to identify any real problems that are found in the classroom. This research also uses a quantitative research approach. Quantitative research is general involves collecting and converting data into numerical form, so that statistical calculations can be made and conclusions drawn. Data is collected by various means following a strict procedure and prepared for statistical analysis to discover complex causal relationship and to determine to what extent one variable influences another.

\section{Procedure}

\section{Observation}

Observation is focused on activities to an object in the class. This method gives monitor of the phenomena systematically investigated. This method also uses in finding concrete data easily and directly. In this case, the writer uses the unstructured or opened observation to know the occurrences within learning process. It may be about the teacher's performance during Classroom Action Research, situation of classroom activities, and students' response in concerning the Talking Stick Method.

2. Interview 
Interview is dialogue done by the interviewer directly to the respondents. The respondent of this study are the sample of this research. The writer asks teacher to know students' difficulties in learning English Vocabulary, students' condition when they join in English class activity, and the strategies of Talking Stick Method that used by the researcher in teaching English' vocabulary.

3. Test

Test plays an important role to collect data. The test that used in this research is pre-test and post-test. The pre-test was done before implementing the Talking Stick Method and also used to know how far the students' competences before implementation of Talking Stick Method. Besides, the post-test is used to see how far the students' competence after using Talking Stick Method.

\section{Instruments}

Besides uses some technique to collecting the data, there are some instruments to collecting the data. They are:

1. Observations

Observation is an instrument for collecting the data about the writer and students' activities in teaching and learning process.

2. Interview

Interview used to get data about the implementation of Class Action Research to the teacher.

3. Questionnaire

The questionnaire is held after implementing Class Action Research

\section{Population and Sample}

The populations of this research are tenth grade students of SMA NEGERI 2 Kabupaten Sorong in the academic year of 2016/2017. They are 247 students and grouped into class X IPA 1 to X IPA 4 and X IPS 1 to X IPS 2

\section{FINDINGS AND DISCUSSION}

In this section, the researcher would like to analyze all data from the research. The data will explain the finding of this study. Entering the class, the students look surprising. In the action of applying the method, most of the students take a part in the learning process. Talking Stick gives them an alternative manner to refresh and to add vocabulary in a more enjoyable way. The procedures of Talking Stick Method are mentioned;

a. The teacher prepares the materials and a stick.

b. The teacher explains the main topic. Then, the students read and learn the materials for some minutes.

c. The teacher gives the stick to a student.

d. The teacher sings a song or plays music while the stick moves one student to another until the song or music stops. 
e. The student who gets the stick must stands up and answers the teacher's questions.

f. Then, the stick rolls on again until most of student gets the stick and takes parts in the learning process.

g. Finally, the teacher gives the evaluation and makes conclusion.

In this treatment, when the researcher shows a stick at the first time, students look amazed and interested. Then, the researcher gives the rules to play the talking stick method. They are afraid and curious to hold the stick. Then, students who have enough vocabulary and confidence are just smile or silent when get the stick and answer the question. Some data are takes from the field notes. In cycle I, the researcher summaries that students are interest with the talking stick method. Although they feel afraid and surprise to get the stick, they still enjoy and participate in learning process. This method gives them new atmosphere in the English class. From cycle I, the researcher analyzes the students' activities as follow;

a. Talking stick method is first method applies to the students of class X IPA 2 SMA Negeri 2 Kabupaten Sorong.

b. Students feel afraid and curious when roll on the stick, get the stick and answer the question.

c. Students take a part in the learning process because interests in the talking stick method.

d. Most of students are not confidence to write English' sentence.

In the first cycle, the test instrument also shows the student's improvement in class. The mean score of post-test are higher than score of pretest. It means that the students' competences are increase, especially in vocabulary and writing. The best score of pre-test is 80 (two students) and the worst score is 30(two students). Then, the best score of posttest is 100 (two students) and the worst score is 60 (four students). In the academic year of 2016/2017 the standardized score (Kriteria Ketuntasan Minimum) in SMAN 2 Kabupaten Sorong is 75 and students were reach the standard score were only 9 students or only $41 \%$ students. In other word, the first cycle was failed. In order to get more data and solve a problem in this first cycle, the researcher continues the cycle I to cycle II. In second meeting, the students look more relax and enthusiastic than first meeting. In this action, the researcher prepares the teaching well. The talking stick method is still used in this cycle. In the process of applying the method, most of the students participate in the learning process.

However, students are common with talking stick. They are look very happy when playing this method. Although some of them forget some vocabulary and wrong in arranging the sentence, all of them write in English confidently. This condition is proof that they develop their competence through talking stick method. The field note also obtains data. The researcher concludes that students are more interested with the talking stick method. They are confidence to write in English and enjoy in learning process. This method is a suitable method to change the 
conventional method that makes students feels bored and afraid in English class. Furthermore, the score of cycle II is better than cycle I. The test instrument also shows the development of students' achievement in the second cycle. The totally score of post-test are higher than score of pre-test. The best score of pre-test is 80 and the worst score is 30 . Then the best score of post-test is 80 and the worst score is 70 and $72 \%$ students in class can reach the standard score. After analyzing the data each cycle, the researcher identifies the result of cycle I and cycle II. In order to understand the data easily, the researcher makes the table as follow;

Table 1. The Analysis Of Students Improvement

\begin{tabular}{|c|c|c|}
\hline ANALYZE & CYCLE I & CYCLE II \\
\hline $\begin{array}{c}\text { The percentage of classical } \\
\text { mastery }\end{array}$ & $41 \%$ & $72 \%$ \\
\hline
\end{tabular}

The table above shows that there is significant improvement from cycle I to cycle II. Students develop their vocabulary mastery, and writing's skill. They also participate and enjoy the English class well. Overall, the talking stick method improves both student's achievement and student's interest in learning process.

Based on the explanation in the first paragraph,the uses of talking stick method in English learning can improve the students' vocabulary mastery. In other hand, the treatments in second grade students of class IPA 2 SMA Negeri 2 Kabupaten Sorong are successful.

\section{CONCLUSION}

After describing the previous chapter, while in the fourth chapter, there were any significant improvement that score percentage of Minimal Mastery Level Criterion (KKM) was improve in cycle 2. This is shows that the treatment was success because more than $70 \%$ students can pass the standard score. Besides that, the result from the instrument, (instruments in this research was questionnaire) it shows that almost all of student has improve their enthusiasm in learning English' vocabulary and more easy to learn. By looking all these point, the researcher summarizes that;

1. The implementation of Talking Stick to improve students' vocabulary mastery at the tenth grade students of SMAN 2 Kabupaten Sorong in the academic year of 2016/2017 works well. Students enjoy and join with fun learning activities in the class. The talking stick method makes them confidence to write in English and easy to remember and learning about English's vocabulary. 
2. The researcher can be said success by seeing the criterion of success when there were more than $70 \%$ students could pass the minimum standard score of English subject which is 75 . This is also can be the evidence that students have significant improvement in their competence, so Ho is rejected. It means that there is significant improvement of students' vocabulary mastery through talking stick.

\section{REFERENCES}

Brown, H. D. (2001). Teaching by Principles ( $2^{\text {nd }}$ ed.). NY: Addison Wesley Longman, Inc.

Dita, I. F.( 2015). The Use of Talking Stick to Improve Students' Speaking Skill(A Classroom Action Research on X MIA-2 Students of SMA Negeri 1 Kesambean). Universitas Brawijaya.

Harmer, (2001). The Practice of English Language Teaching. Harlow: Person Education Limited.

Heny, P. (2013). Increasing Students' English Vocabulary Mastery (NUMBER) Through Talking Stick Method in the First Grade of SDN 11 Limboto Barat. Skripsi Fakultas Ilmu Pendidikan: Universitas Negeri Gorontao.

Hornby, A.S. (1995). Oxford Advanced Learners Dictionary of Current English, London: Oxford University Press.

Kridalaksana, H. 2008. Kamus Linguistik. Jakarta:PT Gramedia Pustaka Utama.

Michael, J. W. (2006). Action Research For Language Teachers. Cambridge: Cambridge University Press.

Muttahidah, N. (2011). Improving Students Vocabulary through Vocabulary Card (A Classroom Action Research in The First Year of MTs Nurul Falah, Ciputat. Skripsi, Departement of English Education, the Faculty of Tarbiyah and Teachers' Training, Syarif Hidayatullah State Islamic :University Jakarta.

Rober, E.S. (2010). Cooperative Learning Teori, Riset dan Praktik. Bandung: Nusamedia 